\title{
Street Tree Diversity in Eastern North America and Its Potential for Tree Loss to Exotic Borers
}

\author{
Michael J. Raupp, Anne Buckelew Cumming, and Erin C. Raupp
}

\begin{abstract}
In light of catastrophic tree losses caused by Dutch elm disease, foresters recommended that the urban forest be diversified. The intent was to create a more sustainable urban forest that would not be decimated by a single pathogen or insect pest. However, recent introductions of deadly borers such as Asian longhorned beetle and emerald ash borer reveal that new introductions can have disastrous consequences for urban forests. An analysis of tree inventories from 12 cities in eastern North America reveals an overabundance of certain genera of trees such as Acer and Fraxinus. Introduced pests with broad host ranges such as the Asian longhorned beetle may be capable of killing or forcing intervention on large numbers of trees. Even cities that have diversified at a low taxonomic level (cultivar or species) may suffer greatly from the depredations of insect pests such as the emerald ash borer that specialize on plants at the generic level. Generalists capable of feeding on plants in several families will create problems for urban forests even when attempts have been made to diversify at higher taxonomic levels. Urban foresters should avoid planting susceptible taxa of trees, especially in cities that are overstocked in these taxa, and consider diversifying greatly the types of trees in cities.
\end{abstract}

Key Words. Asian longhorned beetle; diversity; emerald ash borer; risk; street trees; sustainability; urban forestry.

At one time, the American chestnut, Castanea dentata, was a dominant species of eastern deciduous forests. In the early 1900s, nursery stock from Asia was imported to New York with the chestnut blight fungus, Cryphonectria parasitica. Never having been exposed to this fungus, populations of the American chestnut had little or no resistance to the pathogen. The blight swept through forest stands killing 3.5 billion chestnuts by 1940 (Roane et al. 1986). At the present time, it appears unlikely that the American chestnut will ever assume its dominant role in eastern forests despite some progress to find resistant cultivars and inoculate our forests with less virulent strains of fungi to reduce the lethal impact of this pathogen.

The exotic pest that captured the attention of urban foresters and changed our thinking about the design of urban forests was Dutch elm disease (DED) caused by Ophiostoma ulmi. American elm was one of the most commonly used street trees in the United States before the introduction of DED. American elm has many attributes such as a magnificent habit, fast growth rate, tolerance to a wide range of soils and moisture conditions, and hardiness that made it a favored street tree. Elms were often planted in pure stands that lined the streets of many cities in the United States. DED was first reported in Europe in the 1920s as the agent killing millions of elm trees. It was introduced into the United States from Europe around 1930 in logs to be used for veneer. Since its introduction, it has killed millions of elm trees in the United States and throughout the world. The heavy use of elms in cities and huge costs associated with their removal stretched municipal budgets and left many city streets barren (Sinclair and Campana 1978).

\section{DIVERSITY IN STREET TREE POPULATIONS}

One of the most important lessons learned from these catastrophic events was the dire consequence that low levels of street tree diversity had for urban forests when exotic pests were introduced. Diversity is an important buffer against catastrophic tree loss in natural and managed forest systems alike. The aftermath of the gypsy moth, chestnut blight, and the hemlock woolly adelgid has been a change in the composition of the eastern hardwood forest. Lands once dominated by chestnut (Aesculus), oak (Quercus), and hemlock (Tsuga) now contain a greater diversity of trees such as maple (Acer), birch (Betula), sassafras (Sassafras), black locust (Robinia), and tulip poplar (Liriodendron) (USFS 2003).

What have urban foresters learned about preventing or avoiding losses resulting from exotic pests? The DED disaster forced urban foresters to broaden the scope of factors considered when selecting trees for cities. Before this event, architectural features such as form, habit, color, and environmental tolerances to temperature, soil composition, and moisture regimes were the primary drivers in the plant selection 
process. More recently, the importance of increasing the diversity of tree species in urban forests has found its way into the plant selection process as a buffer against catastrophic losses resulting from pests (Grey and Deneke 1986; Miller 1997; Gerhold and Porter 2000).

One approach to help guide the planning process has been to set diversification goals or guidelines for urban forests. After DED, scientists began creating formulas to help guide the planning process. Barker (1975) was among the first to suggest that street tree plantings needed to be diversified. He recommended that a particular kind of tree should not exceed $5 \%$ of the density of the entire tree population. This concept was later extended to include genera as well as species by Moll (1989) who suggested that no more than $10 \%$ of trees in a community be of the same genus and $5 \%$ be of the same species. Miller and Miller (1991) recognized that one important limitation in attempting to meet a goal of no more than $5 \%$ of any one tree would be the availability of enough proven plant material in a region to implement this goal. They recommended no more than $10 \%$ of a single species as a goal for commonly planted trees. Other authors have set this diversification goal at levels both higher and lower. Grey and Deneke (1986) took a more liberal view and suggested that no tree species should make up more than $10 \%$ to $15 \%$ of the total population. Gerhold and Porter (2000) stressed the importance of diversifying the urban tree population but suggested that a single species or clone along a street should not be prohibited. Santamour (1990) adopted a more comprehensive strategy and suggested that urban forests could be protected from pest outbreaks if no more than $10 \%$ of a single species, $20 \%$ of a single genus, or $30 \%$ of a single family of plants were used.

An important consideration that may be overlooked in the rush to diversify forests is consideration of the adaptability and potential longevity of replacement trees. Richards (1982/ 1983) persuasively argued that trees selected to diversify the urban forest must be well suited to the rigors of the complexly stressful conditions found in urban ecosystems. Using inventory data from Syracuse, New York, Richards (1982/1983) demonstrated that species varied greatly in their ability to adapt to stressful urban conditions. Adaptability and longevity of species in stressful urban habitats must weigh heavily in the tree selection process. Efforts to diversify the urban forest that fail to account for inherent differences of cultivars or species to survive may result in the selection of trees that are ill-suited for the rigors of cities (Richards 1982/1983). The result of poor choices may be increased mortality, reduced lifespan, and ultimately greater costs when failed or failing trees must be removed and replaced.

\section{CURRENT AND FUTURE RISKS TO STREET TREES}

In the last decade, two important and devastating insect pests have been introduced to North America, the Asian long- horned beetle, Anoplophora glabripennis, and the emerald ash borer, Agrillus planipennis. Both species are believed to be Asian in origin and were likely transported to this country as larvae in low-quality lumber used for crating and packing material. In recent years, Asian longhorned beetle populations have become established in several states, including New York (New York City, several cities in Long Island), Illinois (Chicago), New Jersey (Jersey City, Rahway, Carteret), and in Canada (Toronto-Vaughn). Emerald ash borer was initially detected in the summer of 2002 in six counties in Michigan. Since then, detections have been made in more than 30 counties throughout the state. Several counties in Ohio, Illinois, and Indiana have reported infestations and nearby Ontario, Canada, has an infested area. In the spring of 2003, the emerald ash borer arrived in Maryland with shipments of infested nursery stock from Michigan.

These two species of wood-boring beetles share an ability to attack and kill seemingly healthy trees of most age classes in both urban and native forest stands. Despite the enormous destructive potential of these two insects, much is still to be learned about their ability to colonize, use, and kill different species and cultivars of trees commonly planted in cities in North America. However, Sawyer (2003, 2005) compiled lists of trees commonly found in urban forests and categorized them according to their suitability as hosts for Asian longhorned beetle. Host suitability was based on records of relative infestation rates in North America, rearing results, laboratory studies, and Chinese literature. Although some variation in preference and performance has been noted at the specific level for Asian longhorned beetle (Sawyer et al. 2006), intervention tactics, including tree removal and insecticide applications, are still made at the generic level in eradication programs (Sawyer 2003, 2005; USDA 2005). Genera considered to be very good hosts included Acer, Salix, and Ulmus. Good hosts included Aesculus, Betula, and Platanus and occasional hosts included Albizzia, Celtis, Fraxinus, Populus, and Sorbus. Questionable hosts included Hibiscus, Malus, Morus, Prunus, Pyrus, Quercus, Robinia, and Tilia. These are genera in which egg laying has been noted but development has not been generally confirmed in the field. Genera that have no record of use in the United States included Alnus, Eleagnus, Melia, and Ailanthus.

With respect to the emerald ash borer, ash species known to support infestations in North America include $F$. pennsylvanica, $F$. americana, $F$. nigra, and $F$. quadrangulata, and horticultural cultivars of these species (Herms et al. 2004a). In Asia, several ash species are hosts with $F$. mandshurica and $F$. chinensis being primary hosts (Herms et al. 2004a). At the present time, the entire native and cultivated ash resource in North America is considered at risk. This includes at least 16 endemic ash species as well as naturalized species and cultivars used in landscapes (Cappaert et al. 2005). 
The importance of these classifications is that they serve as part of the decision making process used by the United States Department of Agriculture to determine which trees will be removed or treated with insecticides as part of eradication programs. Specifically, for Asian longhorned beetle, Sawyer $(2003,2005)$ indicated that trees in the very good, good, and occasional host categories were ones that are targeted for intervention. This means removal or treatment with insecticides in eradication areas. Trees on the questionable and no record list are not treated with insecticides in eradication programs for Asian longhorned beetle (Sawyer 2003, 2005). Current regulations in the central United States call for the containment, removal, and destruction of all ash trees within 200 to $800 \mathrm{~m}$ ( 220 to $880 \mathrm{yd}$ ) of a tree known to be infested in an outlying site (Siegart and McCullough 2006).

The immediate impact on the local tree community is dramatic when these exotic borers are detected and an eradication program has been established. In New York and Chicago, more than 8,000 trees have been removed in an effort to slow the spread of Asian longhorned beetle. In 2005, in New York, more than 78,000 trees received insecticide treatments as part of the eradication effort on the basis of their susceptibility to Asian longhorned beetle (USDA 2005). The most recent eradication program for Asian longhorned beetle in Middlesex and Union counties in New Jersey called for the removal of more than 8,000 susceptible trees. Furthermore, program officials planned to treat approximately 20,000 additional susceptible trees with systemic insecticides at a cost of more than \$12 million (USDA 2005). In Michigan alone, emerald ash borer has caused $\$ 11.6$ million of damage to landscapes and nurseries and quarantines have restricted the sale of more than $\$ 2$ million of nursery stock (Herms et al. 2004a). Cappaert et al. (2005) report that more than 15 million ash trees are dead or dying as the result of emerald ash borer in Michigan.

Attempts have been made to project potential losses associated with these two invasive borers over larger geographic regions. Nowak et al. (2001) used tree inventories to estimate potential monetary losses resulting from Asian longhorned beetles in nine cities in the United States. The results of this analysis were staggering with an estimated potential loss of approximately 1.2 billion trees at a compensatory value of $\$ 669$ billion. Potential costs associated with removals of urban ash trees in the United States are estimated at $\$ 20$ to 60 billion, a figure that does not include replacement costs (Cappaert et al. 2005).

The objective of our study was to assess the threat to street trees imposed by Asian longhorned beetle and emerald ash borer in 12 cities in eastern North America if they become established and eradication programs are put into place. We collected a sample of tree inventories, identified the most common genera of trees, and enumerated the proportion of trees that might be at risk if these borers escaped quarantines and became widespread.

\section{MATERIALS AND METHODS}

We obtained inventories of street trees from 12 cities and one college campus in the temperate zone of eastern North America. Asian longhorned beetle and emerald ash borer are expected to survive well in the cities in question. Cities included in the study were Wilmington, Delaware; Chicago, Illinois; Lincolnshire, Illinois; Marion, Indiana; Florence, Kentucky; Mt. Rainier, Maryland; Ann Arbor, Michigan; Kansas City, Missouri; New York City, New York; Gastonia, North Carolina; Toledo, Ohio; and Toronto, Ontario. The site in Toronto was the campus of the University of Toronto. All other sites were inventories of street trees. Inventories of trees were all conducted by ground survey using a variety of personnel. In Florence, Gastonia, Kansas City, Lincolnshire, Marion, and Wilmington, inventories were conducted by private firms that specialized in developing inventories of street trees. In other cities such as Ann Arbor, Chicago, Mt. Rainier, New York City, and Toledo, inventories were conducted by trained urban foresters used by the city or state or by municipal employees and volunteers under their supervision. At the University of Toronto, the survey was conducted by the Faculty of Forestry at the St. George Campus (Podolsky 2004). The number of trees included in the inventories and dates of the inventories used in this study were as follows: Wilmington (12,586: 2002), Chicago (416,000: 1991 to 1992), Lincolnshire (3,688: 2003), Marion (6,357: 2003), Florence (6,323: 2002), Mt. Rainier (856: 1996), Ann Arbor (47,045: 1992 initial, continuous 2005), Kansas City (120,816: 2000 to 2001), New York City (453,372: 1995), Gastonia (1,510: 2002), Toledo (76,792: 1985 initial continuous 2005), and Toronto (2839: 2003). Inventories were conducted as complete surveys of all streets in most cities with the exception of Chicago where inventories were based on random samples that were used to extrapolate findings to a city-wide basis (Nowak 1994).

To assess the risk of urban trees in the cities sampled in this study, we adopted the convention of Nowak et al. (2001), Sawyer (2003, 2005), and Siegert and McCullough (2006), namely that intervention decisions would be made at the generic level and directed at genera known to be susceptible to attack by Asian longhorned beetle and emerald ash borer. For Asian longhorned beetle, this included trees in the very good, good, and occasional use categories enumerated by Sawyer (2003). Specific genera included Acer, Salix, and Ulmus in the very good category; Aesculus, Betula, and Platanus in the good category; and Albizzia, Celtis, Fraxinus, Populus, and Sorbus in the occasional use category. For emerald ash borer, trees in the genus Fraxinus were included (Seigert and McCullough 2006). 
For each inventory, tree species were grouped into genera. The proportion of trees in each genus was calculated by dividing the number of trees found in a genus by the total number of trees in the inventory for that city. The ten most common genera of trees were enumerated for each city except Gastonia where 12 genera are reported resulting from equal abundances of some genera. This list of common genera was then compared with the list of hosts associations for the Asian longhorned beetle and emerald ash borer in North America. The proportion of trees at risk of attack and subject to intervention actions such as removal or treatment with insecticide was enumerated for each city.

\section{RESULTS AND DISCUSSION}

Thirty-two genera of trees encompassed the ten most common trees found in the 12 cities studied (Table 1). The most common genus of street tree was Acer. Maples were found in all cities where they comprised from $15 \%$ to $57 \%$ of the street trees (Table 1). The next most common genera were Fraxinus and Quercus. Both were among the ten most common street trees in nine of the cities inventoried. Gleditsia and Ulmus were found in the top ten lists for eight of the cities; and Malus, Prunus, Pyrus, and Tilia were found in seven lists of ten most common trees. The remaining 22 genera were found in less than half of the street tree inventories.

Table 1. Most common genera of trees found in 12 cities in eastern North America*.

\begin{tabular}{|c|c|c|c|c|c|c|c|c|c|c|c|c|}
\hline & Ann & & & & Kansas & & & & New & & & \\
\hline Genus & Arbor & Chicago & Florence & Gastonia & City & Lincolnshire & Marion & Rainier & York & Toledo & Toronto & Wilmington \\
\hline Abies & 0.2 & - & - & - & - & - & - & - & - & - & - & - \\
\hline Acer (ALB) & 39 & $37(5.4)$ & 20 & 35 & 22 & 15 & 52 & 36 & 38 & 57 & 20 & 21 \\
\hline Aesculus (ALB) & - & - & - & - & - & - & - & - & - & 2 & - & - \\
\hline Ailanthus & - & $3(2.0)$ & - & - & - & - & - & - & - & - & - & - \\
\hline Amelanchier & - & - & - & - & - & - & - & - & - & - & - & 4 \\
\hline Betula (ALB) & - & - & - & - & 0.6 & 3 & - & - & - & - & - & - \\
\hline Carpinus & - & - & - & - & - & - & - & 3 & - & - & - & - \\
\hline Carya & 0.7 & - & - & - & 0.5 & - & - & - & - & - & - & - \\
\hline Catalpa & - & $3(2.0)$ & - & - & - & - & 2 & - & - & - & - & - \\
\hline Celtis (ALB) & - & - & 3 & 5 & - & - & 3 & - & - & - & - & - \\
\hline Cornus & - & - & - & - & - & - & - & - & - & - & 2 & - \\
\hline Crateagus & - & - & - & - & - & 3 & - & - & - & - & - & - \\
\hline $\begin{array}{l}\text { Fraxinus } \\
\text { (ALB, EAB) }\end{array}$ & & $12(4.0)$ & 13 & 19 & 10 & 13 & 5 & - & 4 & 9 & - & - \\
\hline Ginko & - & - & - & 1 & - & - & - & 7 & 3 & 1 & 2 & - \\
\hline Gleditsia & - & $22(6.5)$ & - & 10 & - & 3 & - & 8 & 7 & 7 & 3 & 4 \\
\hline Koelreutaria & - & $2(2.1)$ & - & - & - & - & - & 3 & - & - & - & - \\
\hline Liquidamber & - & - & - & - & - & - & - & - & 1 & 2 & - & - \\
\hline Magnolia & - & - & - & 0.1 & - & - & - & - & - & - & - & - \\
\hline Malus & - & - & 3 & 1 & - & 9 & 3 & - & - & 5 & - & 5 \\
\hline Picea & 3 & $3(2.7)$ & 4 & - & - & 12 & 3 & - & - & - & - & - \\
\hline Pinus & 3 & - & 7 & - & 3 & 9 & - & - & - & - & - & 6 \\
\hline Platanus (ALB) & - & - & - & 2 & - & - & 3 & - & 19 & 2 & 9 & - \\
\hline Populus (ALB) & 0.4 & $2(2.1)$ & - & - & 0.8 & - & - & - & - & - & - & - \\
\hline Prunus & 0.5 & - & 3 & - & 0.5 & - & 3 & 5 & - & - & 8 & 3 \\
\hline Pyrus & - & - & 9 & 2 & - & - & 3 & 9 & 7 & 3 & 9 & - \\
\hline Quercus & 4 & - & 6 & 4 & 14 & 11 & - & 6 & 10 & - & 16 & 10 \\
\hline Robinia & - & - & 4 & - & - & - & - & - & - & - & - & - \\
\hline Salix (ALB) & - & - & - & - & 0.1 & - & - & - & - & - & - & - \\
\hline Styphnolobium & - & - & - & - & - & - & - & 3 & 2 & - & - & - \\
\hline Tilia & 5 & $3(2.1)$ & - & 7 & - & - & - & - & 6 & 6 & 4 & 4 \\
\hline Ulmus (ALB) & 3 & $8(6.3)$ & - & 7 & 10 & 5 & 4 & 12 & - & - & - & 7 \\
\hline Zelkova & - & - & - & - & - & - & - & - & - & - & 8 & - \\
\hline $\begin{array}{l}\text { Trees at risk to } \\
\text { ALB and EAB }\end{array}$ & $42 \%$ & $59 \%$ & $36 \%$ & $68 \%$ & $44 \%$ & $36 \%$ & $67 \%$ & $48 \%$ & $61 \%$ & $70 \%$ & $29 \%$ & $37 \%$ \\
\hline
\end{tabular}

*Numbers represent the percent of trees found in each genus relative to the total number of trees inventoried. The ten most common genera are listed for each city except for Gastonia where twelve genera are reported as a result of equal abundances of some genera. ALB and EAB identify genera that are attacked by and support development of Asian longhorned beetle and emerald ash borer, respectively. Standard errors for entire genus or the most common species in the genus are presented parenthetically for Chicago. 
Nowak et al. (2001) used tree inventories to estimate numbers of trees that might be killed and monetary losses resulting from attack by Asian longhorned beetle. We suggest that losses associated with Asian longhorned beetle and emerald ash borer would be quite dramatic in terms of the proportion of trees killed, those subject to removal and replacement as part of eradication programs, and those that will require ongoing protection by one or more insecticide applications if both borers become widespread in the eastern United States. The cities included in this study face the loss or need for insecticide protection of $29 \%$ to $70 \%$ of their street trees (Table 1). The average percentage of trees at risk was $49.7 \%$ (4.0\% standard error) This estimate may be conservative. Recently, Morewood et al. (2003) demonstrated that red oak, Quercus rubra, was used for oviposition and supported larval development of Asian longhorned beetle. They recommended that red oak be considered a potential host when surveys are conducted to detect infested trees. Host associations in Asia include several genera in which no current information is available in the United States.

The analysis provided here points out an important flaw in the way we think about the biologic diversity and pest resistance of our urban forests. Guidelines such as the '10-20-30' rule were developed with the goal of preventing or avoiding the types of catastrophic losses seen with diseases such as DED. What these rules fail to consider is the fact that many, perhaps most, insect pests attack more than one cultivar or species of plant. In recent years, natural forests in the eastern United States have been subjected to attack by hemlock woolly adelgid and emerald ash borer. Although these pests are among the most stenophagous of our invasive species, feeding on Tsuga and Fraxinus, respectively, many exotic insects are far more polyphagous and attack several species, genera, and families of plants. The gypsy moth is known to feed on more than 500 species of plants in families that include trees, shrubs, and vines. The winter moth, Operophtera brumata, recently introduced to New England, has a broad host range that includes oaks, maples, basswood, ash, crabapples, apple, blueberry, and certain spruces. The Asian ambrosia beetle, Xylosandrus crassiusculus, a pest of growing concern in the southern United States, attacks important street trees such as cherry, goldenraintree, sweetgum, oak, elm, crapemyrtle, and magnolia. This borer is reported to attack plants in 46 families (Schedl 1962). As we point out in this article, the Asian longhorned beetle also has a broad host range and attacks and kills trees in several genera and families.

Urban foresters that have used rules such as $10 \%$ diversification may have created a buffer against only the most specialized kinds of exotic plant feeding insects. For example, a city that planted 3 different species of ash, each to the suggested $10 \%$ level, may now face a $30 \%$ loss with the arrival of emerald ash borer. Moreover, when government agencies conduct eradication programs and management decisions are made at higher taxonomic levels, specific or subspecific differences in host susceptibility or adaptation to urban conditions may be meaningless.

What steps can urban foresters take to lessen the impact of exotic pests on urban forests? The search for pest-resistant plant material should be accelerated, and this search should include genera and families of plants that are underrepresented in lists of currently available stock. At the specific level, clonally propagated material may be at an especially high risk to attack by invaders as a result of its inherently narrow genetic base. Diversification at generic, familial, and, perhaps, ordinal levels would help buffer against insect pests or pathogens that specialize at plant genera and species. The identification of resistant varieties will help in this quest. This means that plant breeders and growers must become a large part of the solution. A priority must be placed on pest resistance in breeding programs. Beautiful Fall color or an interesting habit will mean little when a borer or blight has killed a tree.

Exotic plants may also prove to be part of the solution. Plant species that have a long association with an exotic pest may have evolved clever defenses to resist attack or may be better able to tolerate infestations (Herms et al. 2004b). Care will have to be taken to ensure that introduced plants are noninvasive and do not become pests. The impact of exotic plants on local food webs and community structure is yet to be elucidated and remains a concern. In addition, exotic plants have their own complex of potentially devastating exotic pests as evidenced by the eucalyptus pest complex in California (Paine and Millar 2003).

Progress has been made in the area of tree selection with respect to Asian longhorned beetle management. The New Jersey Forest Service in cooperation with USDA has compiled a recommended tree planting list for the Asian longhorned beetle quarantine zone and surrounding areas. This list is reproduced in Table 2 and is available at the following web site: www.aphis.usda.gov/newsroom/hot_issues/alb/ alb_pdfs/ALB-ReplantingList.pdf.

With respect to management of emerald ash borer, a list of recommended replacements for ash in the lower peninsula of Michigan can be found in the Michigan State University Bulletin E-2925 available at the following web site: www. emeraldashborer.info/files/19Alternativetreelisteab.pdf. Consideration must be given when selecting trees from this list, because several recommended trees are known to be highly suitable hosts of Asian longhorned beetle.

Although many species identified on these lists have withstood the test of adaptability and longevity in cities, others have not. One of the goals of urban foresters should be to plant and evaluate untested replacement species for traits such as adaptability and longevity in stressful urban sites. This will enhance the likelihood that attempts to diversify 
Table 2. Recommended tree planting list for the ALB quarantine zone and surrounding areas compiled by the New Jersey Forest Service.

Common name (scientific name)

American arborvitae cultivars (Thuja occidentalis)

American hophornbeam (Ostrya virginiana)

American sweetgum (Liquidambar styraciflua)

American yellowwood (Cladrastis kentukea)

Amur corktree (Phelllodendron amurense)

Baldcypress (Taxodium distichum)

Beech (Fagus spp.)

Blackgum/Tupelo (Nyssa sylvatica)

Callery pear (Pyrus calleryana)

Carolina silverbell (Halesia tetraptera)

Chinese juniper cultivars (Juniperus chinensis)

Crabapple (Malus spp.)

Dawn redwood (Metasequoia glyptostroboides)

Eastern redbud (Cercis canadensis)

Eastern redcedar cultivars (Juniperus virginiana)

European hornbeam (Carpinus betulus)

Flowering dogwood (Cornus florida)

Ginkgo (Ginkgo biloba)

Goldenraintree (Koelreuteria paniculata)

Gray dogwood (Cornus racemosa)

Hawthorn (Crataegus spp.)

Honeylocust (Gleditsia triacanthos)

Japanese tree lilac (Syringa reticulata)

Japanese zelkova (Zelkova serrata)

Katsuratree (Cercidiphyllum japonicum)

Kentucky coffeetree (Gymnocladus dioicus)

Kousa dogwood (Cornus kousa)

Leyland cypress (× Cupressocyparis leylandii)

Littleleaf linden (Tilia cordata)

Magnolia (Magnolia spp.)

Mountain silverbell (Halesia monticola)

Oak (Quercus spp.)

Ornamental cherry (Prunus spp.)

Serbian spruce (Picea omorika)

Serviceberry (Amelanchier spp.)

Silver linden (Tilia tomentosa)

Stewartia (Stewartia spp.)

Swiss stone pine (Pinus cembra)

Tuliptree (Liriodendron tulipifera)

Turkish filbert (Corylus colurna)

Upright white pine (Pinus strobus 'Fastigiata')

White fringetree (Chionanthus virginicus)

urban forests to prevent catastrophic loss to pests will also result in forests that have long-term sustainability (Richards 1982/1983; McPherson 1998).

Another important activity urban foresters should implement is to develop and maintain a complete and current inventory of plant material. This will help identify plant species, genera, and families that are overstocked, identify species that are performing well or not, and facilitate the orderly replacement of these trees. In a prophetic paper, Nowak (1994) pointed out that the city of Chicago should take steps to reduce the number of maples lining its streets. The introduction of the Asian longhorned beetle to Chicago a few years after this admonition has forced this diversification process. Several thousands of maples have now been removed in and around Chicago. Galvin (1999) sounded a similar warning for Mt. Rainier, Maryland, where maples dominate city streets. Despite these warnings, the demand for maples by urban foresters is high and appears to remain so. D'Amato et al. (2002) surveyed urban foresters and vegetation managers in Ohio and found great similarity in the demand for urban trees in 2000 and projected demand for 2005. The list of most requested trees was quite similar and dominated by a few genera, including maple, oak, and ash (Table 3).

Much is known about patterns of host utilization by insect pests in foreign countries. Progress has already been made in identifying the geographic locations and potential threat many of these new invaders pose. As global trade and the intercontinental movement of goods increase, government agencies will need to step up their ability to prevent, intercept, and destroy exotic pests before they enter this country. However, in the long term, biologic diversity at all levels may be the most potent weapon against catastrophic losses in the urban forest.

\section{IMPLICATIONS FOR ARBORICULTURE}

Street trees in a sample of cities in eastern North America were dominated by the genera Acer and Fraxinus. Quercus was also very common. The introduction of deadly, exotic insect pests such as the Asian longhorned beetle and emerald ash borer could have devastating effects on urban forests if they escape federal quarantines. In several of the cities surveyed, more than $50 \%$ of the street trees could be lost or require protection if these pests become widespread. Urban foresters should take steps now to diversify the types of trees that are planted in cities to avoid catastrophic trees losses or massive and expensive tree protection programs.

Table 3. Genera of trees most requested for planting by urban foresters in Ohio*.

\begin{tabular}{lll}
\hline Genus & Demand 2000 (\%) & Demand 2005 (\%) \\
\hline Acer & 17.2 & 17.2 \\
Quercus & 8.3 & 7.6 \\
Fraxinus & 7.1 & 8.4 \\
Amelanchier & 5.8 & 3.4 \\
Tilia & 5.4 & 4.9 \\
Ulmus & 4.2 & 3.6 \\
Pyrus & 3.9 & 2.9 \\
Malus & 3.7 & 5.0 \\
Syringa & 3.3 & 2.9 \\
Prunus & 2.9 & 1.0 \\
\hline
\end{tabular}

*Reprinted from D'Amato et al. 2002. 
Acknowledgments. The authors thank the following people for sharing street tree data: Tony Guiot, Village of Lincolnshire, Illinois; Phil Pearson, City of Marion, Indiana; Mark Govea, Kansas City, Missouri; Joe Castevens, City of Gastonia, North Carolina; Pat O'Brien, City of Toledo, Ohio; Vickram Krishnamurthy, Delaware Center for Horticulture, Romain Alexander, City of Wilmington, Delaware; Paul Bairley and Kay Sicheneder, City of Ann Arbor, Michigan; Jaqueline Lu, New York City Department of Parks and Recreation; and Peter Glenn, City of Florence, Kentucky. Special thanks to Jason Knowles, Davey Resource Group, and Kevin Puls, ACRT, Inc. The manuscript was improved by 2 anonymous reviewers.

\section{LITERATURE CITED}

Barker, P. 1975. Ordinance control of street trees. Journal of Arboriculture 1:212-215.

Cappaert, D., D.C. McCullough, T.M. Poland, and N.W. Siegert. 2005. Emerald ash borer in North America: A research and regulatory challenge. American Entomologist. 51:152-165.

D'Amato, N.E., T.D. Sydnor, and D.K. Struve. 2002. Urban foresters identify Ohio's tree needs. Journal of Arboriculture 28:291-301.

Galvin, M.F. 1999. A method for assessing and managing biodiversity in street tree populations. Journal of Arboriculture 25:124-128.

Gerhold, H.D., and W. Porter. 2000. Selecting trees for community landscapes, pp.154-168. In Handbook of Urban Forestry. Kuser, J.E., Ed. Kluwer Academic, New York, NY. 434 pp.

Grey, G.W., and F.J. Deneke. 1986. Urban Forestry, 2nd edition. Wiley, New York, NY. 299 pp.

Herms, D.A., A.K. Stone, and J.A. Chatfield. 2004a. Emerald ash borer: The beginning of the end of ash in North America? pp. 62-71. In Ornamental Plants: Annual Reports and Research Reviews 2003. Chatfield, J.A., Draper, E.A., Mathers, H.M., Dyke, D.E., Bennett, P.J., and Boggs, J.F., Eds. OARDC/OSU Extension Special Circular 193. $200 \mathrm{pp}$.

Herms, D., D. Smitley, P. Bonello, and D. McCullough. 2004b. Evaluation of resistance of Asian and North American ashes to emerald ash borer, p. 43. In Proceedings of XV USDA Interagency Research Forum on Gypsy Moth and Other Invasive Species. Gottshalk, K., Ed. Annapolis, MD. 98 pp.

McPherson, E.G. 1998. Structure and sustainability of Sacramento's urban forest. Journal of Arboriculture 24: 174-190.

Miller, R.W. 1997. Urban Forestry, 2nd edition. Prentice Hall, NJ. 502 pp.

Miller, R.H., and R.W. Miller. 1991. Planting survival of selected street tree taxa. Journal of Arboriculture 17: 185-191.
Moll, G. 1989. Improving the health of the urban forest, pp. 119-130. In A Resource Guide for Urban and Community Forests. Moll, G., and Ebenreck, S., Eds. Island Press, Washington, DC. 349 pp.

Morewood, W.D., P.R. Neiner, J.R. McNeil, J.C. Sellmer, and K. Hoover. 2003. Oviposition preference and larval performance of Anoplophora glabripennis (Coleoptera: Cerambycidae) in four Eastern North American hardwood tree species. Environmental Entomology 32:1028-1034.

Nowak, D.J. 1994. Urban forest structure: The state of Chicago's urban forest. USDA. Tech. Rep. NE-186. 118 pp.

Nowak, D.J., J.E. Pasek, R.A. Sequeira, D.E. Crane, and V.C. Mastro. 2001. Potential effect of Anoplophora glabripennis (Coleoptera: Cerambycidae) on urban trees in the United States. Journal of Economic Entomology 94: 116-122.

Paine, T.D., and J.G. Millar. 2003. Biological control of introduced pests in eucalyptus in California. 1st International Symposium on Biological Control of Arthropods. USDA-Forest Service FHTET-03-05. 574 pp.

Podolsky, L. 2004. Species diversity and age class structure: The University of Toronto's urban forest. FOR3008H. Research Paper in Forest Conservation. 44 pp.

Roane, M.K., G.J. Griffin, and J.R. Elkins. 1986. Chestnut blight, other Endothia diseases, and the genus Endothia. American Phytopathological Society Monograph Series. $53 \mathrm{pp}$.

Richards, N.A. 1982. 1983. Diversity and stability in a street tree population. Urban Ecology 7:159-171.

Santamour, F.S. 1990. Trees for urban planting: Diversity, uniformity, and common sense. Proceedings of the 7th Conference of the Metropolitan Tree Improvement Alliance. 7:57-65.

Sawyer, A.J. 2003. Annotated categorization of ALB host trees. http://www.aphis.usda.gov/alb/hotlist.pdf (accessed 9/29/06).

- 2005. Annotated Categorization of ALB Host Trees [revised]. USDA-APHIS-PPQ, Otis Pest Survey Detection and Exclusion Laboratory.

Sawyer, A.J., W.S. Panagakos, and S.M. Kreuz. 2006. Life tables for the Asian longhorned beetle on its principal hosts in the United States. Poster, XVII USDA Interagency Research Forum on Gypsy Moth and Other Invasive Species. Annapolis, Maryland.

Schedl, K.E. 1962. Scolytidae und Platypodidae Afrikas. II. Review of Entomology Mozambique 5:1-594.

Siegart, N.W., and D.C. McCoullogh. 2006. Potential production of emerald ash borer adults: Tree, site, and landscape level applications. Poster, XVII USDA Interagency Research Forum on Gypsy Moth and Other Invasive Species. Annapolis, MD. 
Sinclair, W.A., and R.J. Campana. 1978. Dutch elm disease: Perspectives after 60 years. Northeast Regional Research Publication. 8(5). 52 pp.

USFS. 2003. Gypsy moth homepage. www.fs.fed.us/ne/ morgantown/4557/gmoth/ (accessed 9/29/06).

USDA. 2005. USDA to treat trees in Middlesex and Union Counties New Jersey for Asian longhorned beetle. http:// www.aphis.usda.gov/lpa/issues/alb/ (accessed 3/12/06).

\section{Michael J. Raupp (corresponding author) \\ Professor of Entomology \\ Department of Entomology \\ 4112 Plant Sciences \\ University of Maryland \\ College Park, MD, 20742 U.S. \\ mraupp@umd.edu}

\section{Anne Buckelew Cumming \\ Forester \\ Urban and Community Forestry Program \\ USDA Forest Service \\ 180 Canfield Street \\ Morgantown, WV 26505 U.S.}

\author{
Erin C. Raupp \\ Research Assistant \\ Department of Entomology \\ 4112 Plant Sciences \\ University of Maryland \\ College Park, MD, 20742 U.S.
}

Résumé. À la lumière des pertes catastrophiques en arbres causées par la maladie hollandaise de l'orme, les forestiers recommandent que la forêt urbaine soit diversifiée. Le but est de créer une forêt plus soutenue qui ne sera pas décimée par un unique agent pathogène ou insecte parasite. Cependant, les introductions récentes d'insectes perceurs mortels tels que le longicorne asiatique et l'agrile du frêne révèle que les nouvelles introductions peuvent avoir des conséquences dévastatrices pour les forêts urbaines. Une analyse de l'inventaire des arbres de douze villes de l'Est de l'Amérique du Nord révèle une surabondance de certains genres tels que Acer et Fraxinus. L'introduction de parasites avec un large spectre d'hôtes tels que le longicorne asiatique pourrait être capable de tuer ou de forcer une intervention sur de grands nombres d'arbres. Même les villes qui ont diversifiées leurs espèces avec de faibles quantités de sujets (en cultivar ou en espèce) peuvent souffrir grandement de la déprédation causée par des insectes parasites tels que l'agrile du frêne qui se spécialise sur toutes les espèces du genre Fraxinus. Ces généralistes capables de s'alimenter sur les végétaux de plusieurs familles vont créer des problèmes pour les forestiers urbains, et ce même lorsque des tentatives auront été faites pour une diversification importante au niveau taxonomique. Les forestiers urbains devraient éviter de planter des espèces d'arbres susceptibles, particulièrement lorsque ces mêmes espèces sont déjà surabondantes dans les villes, et considérer au contraire de diversifier grandement les espèce d'arbres dans les villes.

Zusammenfassung. Im Licht der katastrophalen Baumverluste durch die Ulmenkrankheit rieten Forstexperten zu mehr Artenvielfalt in Stadtwäldern. Die Absicht war, einen vielfältigeren Wald zu kreieren, der nicht durch ein einziges Insekt oder Krankheitserreger dezimiert werden kann. Trotzdem hat die kürzliche Einführung von tödlichen Bohrinsekten gezeigt, dass neue Einführungen desaströse Konsequenzen für die Stadtwälder haben können. Eine Analyse der Baumeinführungen in 12 Städten in Nordostamerika zeigte ein übermäßiges Vorkommen von Bäumen aus den Familien Acer und Fraxinus. Eingeführte Schädlinge mit breitem Wirtsspektrum, so wie der asiatische Langhornkäfer, haben die Fähigkeit, große Zahlen von Bäumen zu töten oder Interventionen zu fordern. Sogar Städte, die auf einem niedrigen taxonomischen Level (Kultivar oder Art) diversifiziert können große Verluste durch die Aktivität von Schadinsekten wie z.B. den Eschenbohrer erleiden, welcher sich auf ganze Pflanzenfamilien spezialisiert hat. Generalisten untern den Schadinsekten, die in mehreren Familien fressen, können auch für solche Wälder ein Problem darstellten, die sich bereits auf höherem taxonomischen Level diversifiziert haben. Stadtforstleute sollten anfällige Familien von Bäumen bei Pflanzungen in Städten vermeiden, besonders in Städten, die mit diesen Arten bereits überversorgt sind, und sich mehr auf die Diversifizierung von Baumtypen ausrichten.

Resumen. A la luz de las catastróficas pérdidas de árboles causadas por la enfermedad holandesa del olmo, los dasónomos urbanos han recomendado que los bosques urbanos deben ser diversificados. El intento fue crear un bosque urbano más sustentable que pudiera no ser afectado pro un solo patógeno o plaga de insecto. Sin embargo, recientes introducciones de barrenadores letales, como el escarabajo asiático de alas largas y el barrenador del fresno, revelan que nuevas introducciones puedes tener consecuencias desastrosas para los bosques urbanos. Un análisis de inventarios de árboles de doce ciudades del este de Norte América revela una sobreabundancia de ciertos géneros de árboles tales como Acer y Fraxinus. Las plagas introducidas con amplio rango de hospederos, tales como el escarabajo asiático de alas largas, pueden ser capaces de matar o forzar la intervención de un gran número de árboles. Aún en ciudades que han sido diversificadas a un bajo nivel taxonómico (cultivar o especie) pueden sufrir gravemente de depredaciones de tales plagas de insectos, como el escarabajo del fresno que se especializa en plantas a nivel de género. Los insectos generalistas, capaces de alimentarse de plantas de varias familias, crearán problemas para los bosques urbanos aún cuando se han hecho intentos de diversificar a un nivel taxonómico más alto. Los dasónomos urbanos deberían evitar plantar taxa de árboles susceptibles, especialmente en ciudades que tienen altas concentraciones de tales taxa y considerar la diversificación con otros tipos de árboles. 